\title{
Possibilities of using soil microarthropods, with emphasis on mites (Arachnida, Acari, Mesostigmata), in assessment of successional stages in a reclaimed coal mine dump (Pszów, S Poland)
}

\author{
GRAŻYNA MADEJ and MONIKA KOZUB
}

Department of Ecology, University of Silesia, Bankowa 9, 40-007 Katowice, Poland

Corresponding author: Grażyna Madej, grazyna.madej@us.edu.pl

(Received on 17 April 2012; Accepted on 19 May 2014)

\begin{abstract}
The usefulness of 2 methods for biomonitoring of the effects of land rehabilitation were compared in Pszów (Upper Silesian Coal Basin, south of Poland). Thirty-one species of mesostigmatid mites were collected from 3 study plots representing different stages of restoration of the mine dump Wrzosy in Pszów and community structure of the mites was analysed. There was a general trend for mesostigmatid species richness, diversity, and density to increase with the development of vegetation. The dominant early successional mesostigmatid species was the phoretic Hypoapis claviger. During this study, 4616 specimens of soil microarthropods were extracted in total. They were classified according to the Biological Soil Quality Index (QBS). We tested the sensitivity and usefulness of this index for monitoring of soil quality and found its good relationship with successional stages in the reclaimed mine dump. Thus the QBS index seems to be an efficient index for monitoring the effects of restoration in mine dumps. It is a simpler, quicker, and cheaper bioindicator method than the earlier method based on community structure analysis of mesostigmatid mites.
\end{abstract}

Keywords: QBS, soil quality, microarthropods, mites, Mesostigmata, land rehabilitation, mine dump

\section{INTRODUCTION}

One of the most negative effects of coal mining are large mine dumps, which have to be reclaimed afterwards. The formation of soil is crucial for successful reclamation of these special habitats (BATTIGELLi 2011). A very important part of the soilforming process are biological processes connected with colonization and activity of soil fauna. Soil fauna perform a central role in the restoration of these degraded biological habitats (WITT 1997). Information on microarthropod colonization of restored landscapes is important not only for the recovery, but also in view of their role in soil formation. The soil-forming process is very slow. Several studies have examined the effectiveness of reclamation effort during succession in post-mining sites, and the 
participation of soil fauna in this process (HuTSON 1980; Dunger 1989; Topp et al. 2001; Hendrychová 2008). According to Paoletti (1999), soil animal communities are successfully used for soil health evaluation. Soil microarthropods are widely applied as useful bioindicators of success in reclaimed soils (BATTIGELLI 2011). According to Wanner \& Dunger (2002), Dunger \& Voigtländer (2009), these organisms are good environmental quality indicators of mine-site soil conditions.

Acari are microarthropods, which constitute an important component of soil fauna. Recently research has focused on the role of mites (Acari) in biomonitoring and their importance as soil bioindicators (GULVIK 2007). These microarthropods are abundant inhabitants even in strongly disturbed soils. Among them, predatory Gamasina are highly mobile mites, which have been reported to colonize quickly and inhabit very different developmental stages of new post-mining sites (KoEHLER 2000; MADEJ 2004).

In assessing changes in the efficiency of reclamation management, practical indicators are needed (Turnhout et al. 2007). For example, Andrés \& MATEOS (2006) used soil mesofaunal bioindicators to evaluate the progress of post-mining forest restoration.

Biomonitoring techniques vary from very simple to very complex (GARDI et al. 2009). The measure of invertebrate abundance and diversity is often used for monitoring purposes. Different methods can be used to measure the abundance and diversity of soil invertebrates according to taxonomic and functional groups. According to PARMENTER \& MAC MAHON (1992), an analysis of the faunal community development can be used as an evaluation method for successful reclamation. The characteristics of the faunal community in soil are closely related to soil quality (YAN et al. 2011). There are many examples of the use of community structure analysis of mesostigmatid mites for environmental monitoring in areas of post-industrial wastelands (MADEJ 2004). However, these methods, based on taxonomy, are time-consuming. Identification at the species level represents a major problem to the use of soil invertebrates as indicators (Oliver \& BeAtTIE 1996) The discipline of taxonomy is in decline and the number of taxonomists is rather low (Majer 2009). According to Oliver \& BeAtTIE (1993, 1996), morphospecies may be used as surrogates for species in some environmental monitoring and conservation. Recently, GARDI et al. (2002) and PARISI et al. (2005) proposed the Biological Soil Quality Index (Qualità Biologica del Suolo, QBS, also known as QBS-ar) as a new monitoring tool to evaluate the soils, based on the types of soil microarthropods present, without the need to identify to species level. The QBS index is mainly based on the life-form approach in a soil sample, allowing a fast assessment of soil microarthropod fauna. The index is based on the concept that the higher is the soil quality, the higher will be the number of microarthropod groups well adapted to the soil habitat (PARISI et al. 2005). According to TuRBÉ et al. (2010), its versatility and relative ease of use mean that it could be used in largescale sampling and monitoring schemes. The QBS has already been applied to assess the biological quality of soil in different natural and anthropogenically transformed ecosystems (Hartley et al. 2008, 2012; Madej et al. 2011; SAntorufo et al. 2012). DiCKINSON et al. (2005) have proposed this index for use in the reclamation of brownfield land. According to BLASI (2009), this index can also be used for monitoring the effects of forest restoration. This indicator was applied to the topsoil of a reclaimed 
waste disposal site by MENTA et al. (2008). The QBS has already been recognized in Poland as useful biological indicator of soil quality in post-mining sites developed under primary and spontaneous succession (MADEJ et al. 2011).

This paper addresses the possibilities of assessing biological soil quality in the distinguished successional chronosequence of a reclaimed mine dump. We used 2 bioindicators to compare our research results: the QBS index (based on soil microarthropods) and an analysis of the composition and structure soil predatory mesostigmatid mite communities. The aims of this study were: (1) to evaluate the usefulness of the QBS index in a reclaimed post-mining chronosequence; and (2) to analyse changes in structure and organization of mesostigmatid communities of newly created habitats during a very early stage of colonization and later stages of succession in a reclaimed mine dump.

\section{MATERIALS AND METHODS}

The study was carried out on a reclaimed mine dump "Wrzosy" in Pszów (Upper Silesian Coal Basin, southern Poland). The dump belongs to the "Rydułtowy - Anna Ruch II" coal mine. The mine used it in 1954-1997, when around $5 \mathrm{mln} \mathrm{m}^{3}$ of spoil and tailings were dumped there, i.e. the mineral waste resulting from the actual mining of coal and its processing (СісHY 2004). Mine dumps have a high salt content and toxic heavy metal levels (As, Cd, Cr, Ni and Pb) (GwiżDż 2008). The dumped material is harmful to plant growth and creates extreme conditions for soil organisms, sometimes highly unstable (ArocENA et al. 2010). The coal mine dump "Wrzosy" was reclaimed by using conventional reclamation methods applied for transformation of industrial waste into a biological environment. Bioremediation was started in 1996, by covering with turf with humus. The dump was then rehabilitated with a mixture of grass (100-120 kg/ha) with NP-fertilization (100 kg/ha) (GAWĘDA \& LoRENC 2000).

Three sampling plots (chronosequence P1-P3) were selected, representing different stages of restoration and having different environmental conditions (Table 1). Reclaimed sites were gradually covered by young trees and shrubs (Table 2). Tree numbers and vegetation cover increased at the later stage of succession (P3). Effective rehabilitation of this land requires organic matter in the surface layer: on spoil and tailings, similar to the humus horizon in natural soils (GILEWSKA et al. 2001).

Table 1. Environmental parameters at 3 investigated sites in the reclaimed mine dump in S Poland

\begin{tabular}{lccc}
\hline Environmental parameter & P1 & P2 & P3 \\
\hline Mean soil water content $\pm \mathrm{SD}(\%)$ & $15.4 \pm 10.08$ & $9.93 \pm 8.17$ & $36.0 \pm 26.2$ \\
Mean soil temperature $\pm \mathrm{SD}\left({ }^{\circ} \mathrm{C}\right)$ & $15.9 \pm 12.55$ & $12.0 \pm 9.04$ & $10.0 \pm 5.03$ \\
Number of plant species (tree species) & $9(2)$ & $13(2)$ & $7(8)$ \\
Plant cover $(\%)$ & 20 & 20 & 80 \\
Soil pH & 6.8 & 7.0 & 7.2 \\
\hline
\end{tabular}


Table 2. List of plant species present at 3 investigated sites in the reclaimed mine dump in S Poland

\begin{tabular}{|c|c|c|c|}
\hline Plant species & $\mathrm{P} 1$ & $\mathrm{P} 2$ & P3 \\
\hline \multicolumn{4}{|l|}{ Trees and shrubs } \\
\hline Acer pseudoplatanus L. & & & + \\
\hline Corylus sp. & & + & + \\
\hline Crataegus monogyna Jacq. & & & + \\
\hline Betula pendula Roth. & & + & + \\
\hline Populus nigra $\mathrm{L}$. & + & & \\
\hline Fraxinus excelsior $\mathrm{L}$. & + & & \\
\hline Quercus robur $\mathrm{L}$. & & & + \\
\hline Rubus sp. & & & + \\
\hline Salix caprea L. & & & + \\
\hline Salix fragilis $\mathrm{L}$. & & & + \\
\hline \multicolumn{4}{|l|}{ Herbs } \\
\hline Achillea millefolium $\mathrm{L}$. & & + & \\
\hline Anthemis arvensis $\mathrm{L}$. & + & & \\
\hline Artemisia vulgaris $\mathrm{L}$. & + & + & + \\
\hline Aster novi-belgii $\mathrm{L}$. & & + & \\
\hline Conyza canadensis (L.) Cronquist & & + & \\
\hline Daucus carota $\mathrm{L}$. & + & & \\
\hline Erigeron annuus (L.) Pers & + & & \\
\hline Festuca rubra L. & & + & \\
\hline Heracleum sphondylium L. & & & + \\
\hline Holcus lanatus L. & & + & \\
\hline Melilotus officinalis (L.) Lam. & + & & + \\
\hline $\begin{array}{l}\text { Phragmites australis (Cav.) Trin.ex } \\
\text { Steud }\end{array}$ & & & + \\
\hline Poa pratensis $\mathrm{L}$. & & + & \\
\hline Poa nemoralis $\mathrm{L}$. & & + & \\
\hline Solidago canadensis L. & + & + & \\
\hline Sonchus asper (L.) Hill & & + & \\
\hline Tanacetum vulgare $\mathrm{L}$. & + & + & + \\
\hline Taraxacum officinale Web & & & + \\
\hline Trifolium sp. & + & & \\
\hline Tussilago farfara & + & & + \\
\hline Urtica dioica $\mathrm{L}$. & & + & \\
\hline Vicia sativa $\mathrm{L}$. & & + & \\
\hline Moss & & & + \\
\hline Number of plant species & 11 & 15 & 15 \\
\hline
\end{tabular}


At each site, 20 soil samples were taken $\left(10 \times 10 \times 10 \mathrm{~cm}^{3}\right.$ each), i.e. 5 samples per site on each sampling date in 2007: 27 April (spring), 5 June (summer), 27 October (autumn), and 1 December. Thus a total of 60 soil samples were collected and extracted for soil invertebrates. Soil fauna was extracted from the soil samples by using a modified Berlese-Tullgren apparatus for 5 days. Microarthropods were next classified to orders, and the Mesostigmata were identified to species level.

Biological soil quality at the investigated sites was evaluated by using the Biological Soil Quality Index (QBS). This index is based on microarthropod groups present in a soil sample. It is a sum of the highest eco-morphological index (EMI) values of each taxon (PARISI et al. 2005). In total, 4616 soil microarthropods were extracted and classified for use in this index. They were divided into 14 taxa (Table 3).

Table 3. Density (ind. $/ \mathrm{m}^{2}$, mean $\pm \mathrm{SD}$ ) of microarthropods at 3 investigated sites in the reclaimed mine dump in S Poland

\begin{tabular}{lccc}
\hline \multicolumn{1}{c}{$\begin{array}{c}\text { Microarthropod } \\
\text { groups }\end{array}$} & P1 & P2 & P3 \\
\hline Acari & $880 \pm 294$ & $4355 \pm 226$ & $2835 \pm 424$ \\
Collembola & $1215 \pm 162$ & $3535 \pm 510$ & $3870 \pm 1251$ \\
Coleoptera (adults) & $75 \pm 12$ & $245 \pm 37$ & $220 \pm 63$ \\
Coleoptera (larvae) & $175 \pm 38$ & $225 \pm 33$ & $170 \pm 18$ \\
Diptera (adults) & $35 \pm 7$ & $30 \pm 6$ & $60 \pm 23$ \\
Diptera (larvae) & $20 \pm 7$ & $90 \pm 14$ & $210 \pm 44$ \\
Araneae & $95 \pm 35$ & $165 \pm 31$ & $170 \pm 30$ \\
Isopoda & & $40 \pm 7$ & $85 \pm 21$ \\
Chilopoda & $30 \pm 9$ & $285 \pm 54$ & $1275 \pm 203$ \\
Diplopoda & & $5 \pm 2$ & $165 \pm 28$ \\
Hymenoptera & $335 \pm 167$ & $295 \pm 118$ & $115 \pm 35$ \\
Symphyla & $25 \pm 7$ & $45 \pm 13$ & $345 \pm 93$ \\
Hemiptera & $735 \pm 302$ & & $5 \pm 2$ \\
Protura & & & 13 \\
\hline Number of taxa & 11 & 12 & \\
\hline
\end{tabular}

The Mesostigmata were identified using the keys of BREGETOVA (1977) and KARG (1993). The composition of mesostigmatid communities was described through their dominance structure. Dominance classes were used according to MADEJ (2004), resulting in the following 6 classes: superdominant $\geq 30.1 \%$, eudominant $10.1-30.0 \%$, 
dominant $5.1-10.0 \%$, subdominant $2.1-5.0 \%$, recedent $1.1-2.0 \%$, and subrecedent $\leq 1.0 \%$ all individuals. We investigated patterns of dominance structure of these mite communities according to TROJAN et al. (1982).

The dynamics of the mesostigmatid community was estimated by calculating the species turnover rate $T$ (MÜHLENBERG 1993):

$$
T=\frac{J+E}{S_{1}+S_{2}},
$$

where $J$ is the number of additional species from stage 1 to $2 ; E$ is the number of species lost between stage 1 and 2; $S_{1}$ is the number of species at stage 1; and $S_{2}$ is the number of species at the subsequent stage 2 .

Theoretical total species richness of mesostigmatid mites was calculated using Chao 1, i.e. a non-parametric method for estimating species richness. It is based on the number of rare species: singletons and doubletons (Снао 1987). The species diversity and evenness of mites was assessed using the Shannon $\left(H^{\prime}\right)$ and Pielou $(J)$ indices. Rank abundance plots were produced to examine the species distribution, with one axis of the curve representing species rank in a community and the other axis representing species abundance (MAGURRAN 1988).

The reproductive mode (sexual or parthenogenetic) of mesostigmatid mites was ascribed according to published data (Oliver 1971; Walter \& Oliver 1989; Walter \& Kaplan 1990; Norton et al. 1993; Walter \& LindQuist 1995; Ruf 1996). A linear trend line determined for parthenogenesis was fit to the data and used to calculate the $R^{2}$. The equation for the best-fit trend line determined by the Excel spreadsheet is presented in Fig. 6.

Because of the non-normal distribution of most groups and species, all data on abundance were transformed using $\ln (x+1)$, where $x$ is the mean number of individuals per site. The significance of differences between sites was estimated using the non-parametric test Kruskal-Wallis ANOVA and Mann-Whitney test as a post hoc test.

Non-metric multidimensional scaling (nMDS) ordinations, derived from BrayCurtis similarity matrices, were carried out to display differences in the structure of mesostigmatid communities. Two-way analysis of similarities (ANOSIM) was performed to assess differences in mite community structure between sites and over time. $R$-values greater than 0.75 indicate good separation of groups (CLARKE \& GoRLEY 2001). When significant differences were detected between sites, the data matrices were further analysed by the multivariate similarity percentage procedure (SIMPER), to determine which species contributed most to the dissimilarity. Clarke (1993) suggests that stress $<0.10$ is ideal (configuration is close to actual dissimilarities).

All statistical analyses were performed with the CAP 4 software package (version 4.0) (SEABY \& HENDERSOn 2007). Rank abundance plots were created with Species Diversity \& Richness 4 software (SEABy \& Henderson 2006). 


\section{RESULTS}

Parallel to increasing successional processes, also densities of Collembola, Diptera larvae, Araneae, Isopoda, Chilopoda, Diplopoda, and Symphyla increased. The Protura were less abundant only at P3 (Fig. 3). The number of microarthropod taxa and the value of the QBS index increased during succession. According to the increasing values of QBS, the soils of the study sites can be ordered as follows: $\mathrm{P} 1<\mathrm{P} 2<\mathrm{P} 3$ (Table 4).

Table 4. Mean, maximum, and median QBS values (Biological Quality of Soil, based on microarthropods) and coefficient of variation at 3 investigated sites in the reclaimed mine dump in S Poland. Lack of statistically significant differences is denoted with the same letters

\begin{tabular}{llll}
\hline Statistic & P1 & P2 & P3 \\
\hline Min & 67 & 107 & 121 \\
Max & 91 & 126 & 147 \\
Median & 79 & 116 & 137 \\
Mean \pm SD & $79 \pm 9.9^{\mathrm{b}}$ & $117 \pm 7.7^{\mathrm{a}}$ & $141 \pm 20.8^{\mathrm{a}}$ \\
Coefficient of variation $(\%)$ & 12.5 & 6.6 & 14.7 \\
\hline
\end{tabular}

The average abundance of Mesostigmata ranged from 260 ind. $/ \mathrm{m}^{2}$ at P1 to 2095 ind. $/ \mathrm{m}^{2}$ at $\mathrm{P} 3$ (Table 5). A total of 31 mesostigmatid species were recorded during the survey period. Species number was lowest in the sparsely vegetated site P1 (6). The richness estimated with Chao 1 varies from 10 species (P1) to 33 (P2), and represents between $60 \%$ and $52 \%$ of expected richness (Table 5). The highest number of mesostigmatid species was found at the oldest site P3. The total number of species

Table 5 . Density mean \pm SD (ind. $\left./ \mathrm{m}^{2}\right)$, observed $(S)$ and expected number of mesostigmatid species $\left(S_{\text {Chao }}\right)$, Shannon diversity index $\left(H^{\prime}\right)$ and evenness index $(e)$ at 3 investigated sites in the reclaimed mine dump in S Poland. Lack of statistically significant differences is denoted with the same letters

\begin{tabular}{llll}
\hline Community parameter & $\mathrm{P} 1$ & $\mathrm{P} 2$ & $\mathrm{P} 3$ \\
\hline Density mean $\pm \mathrm{SD}\left(\right.$ ind.$\left./ \mathrm{m}^{2}\right)$ & $260 \pm 281^{\mathrm{a}}$ & $981 \pm 513^{\mathrm{ab}}$ & $2095 \pm 1537^{\mathrm{b}}$ \\
$S$ & 6 & 17 & 19 \\
$S_{\text {Chao }}$ & 10 & 33 & 20 \\
$H^{\prime}$ & 1.29 & 2.21 & 2.13 \\
$e$ & 0.61 & 0.43 & 0.44 \\
\hline
\end{tabular}


and total density increased along a successional gradient (Table 5). Species turnover increased during succession. The change in total species richness was great between P2 and P3, since the 11 species lost were replaced by 9 other species (Fig. 1).

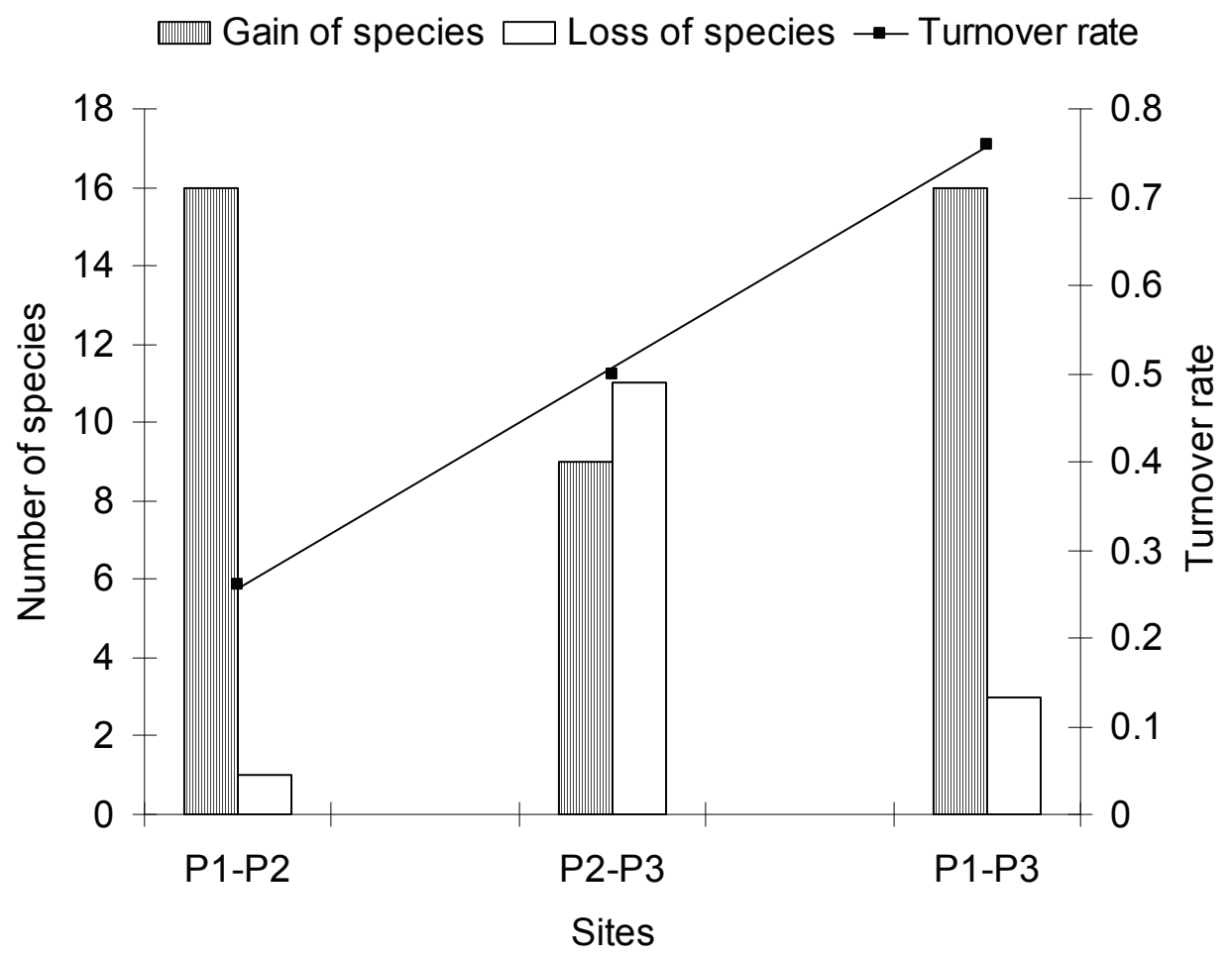

Fig. 1. Gain, loss, and turnover rate of mesostigmatid species at 3 investigated sites in the reclaimed mine dump in S Poland

The Shannon $\left(H^{\prime}\right)$ index of diversity ranged from 1.29 at P1 to 2.21 at P2. Evenness (e) varied between 0.43 and 0.61, and was particularly low at P2 and P3 (Table 5). Rank-abundance plots showed different trends in community organization for the 3 sites. Communities P2 and P3 in Fig. 1 were more diverse than community P1 because the lines are more even (smaller slope) and because they have a higher species richness (Fig. 2). The species composition and dominance structure of the Mesostigmata changed with the development of the habitat. At site P1 the dominance structure was very uneven, with one superdominant Hypoaspis claviger $(D=48.1 \%)$ and 2 udominant species Pergamasus crassipes, Cheiroseius necorniger, and with a very short tail of 2 low-abundance species (Fig. 3). At site P2, the community structure was dominated by one superdominant Ololaelaps sellnicki $(D=40.98 \%)$. This community 


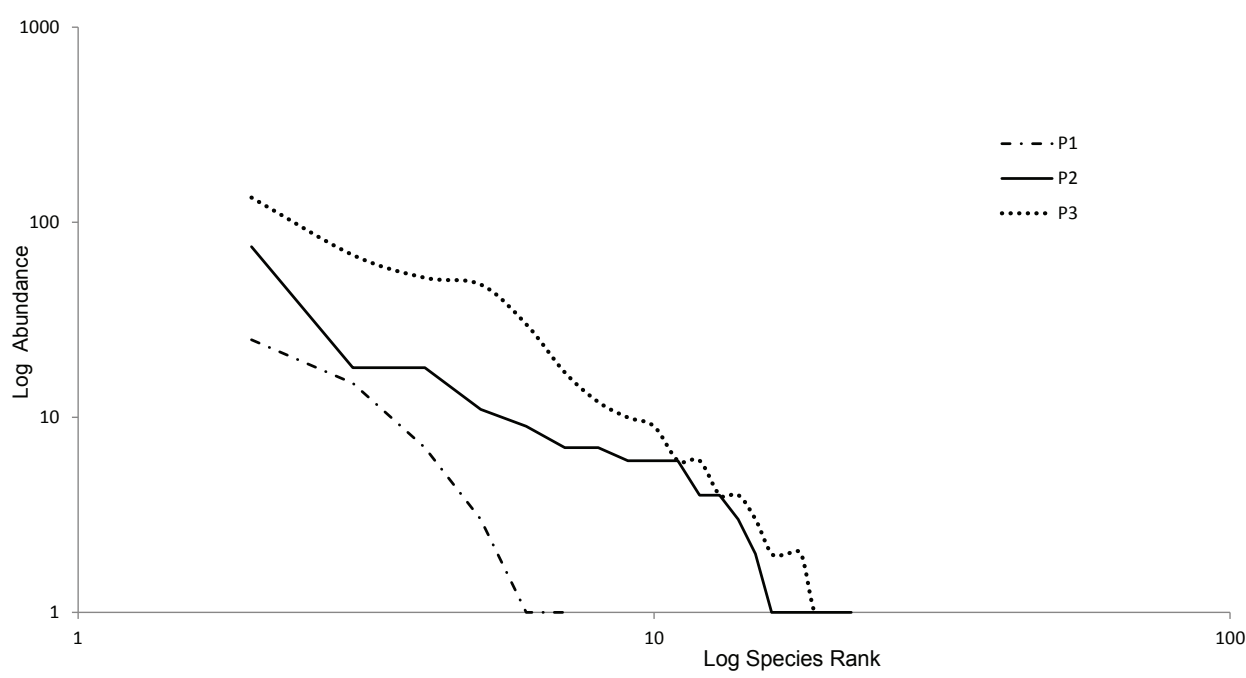

Fig. 2. Rank-abundance curves (log scale) for 3 investigated sites in the reclaimed mine dump in S Poland

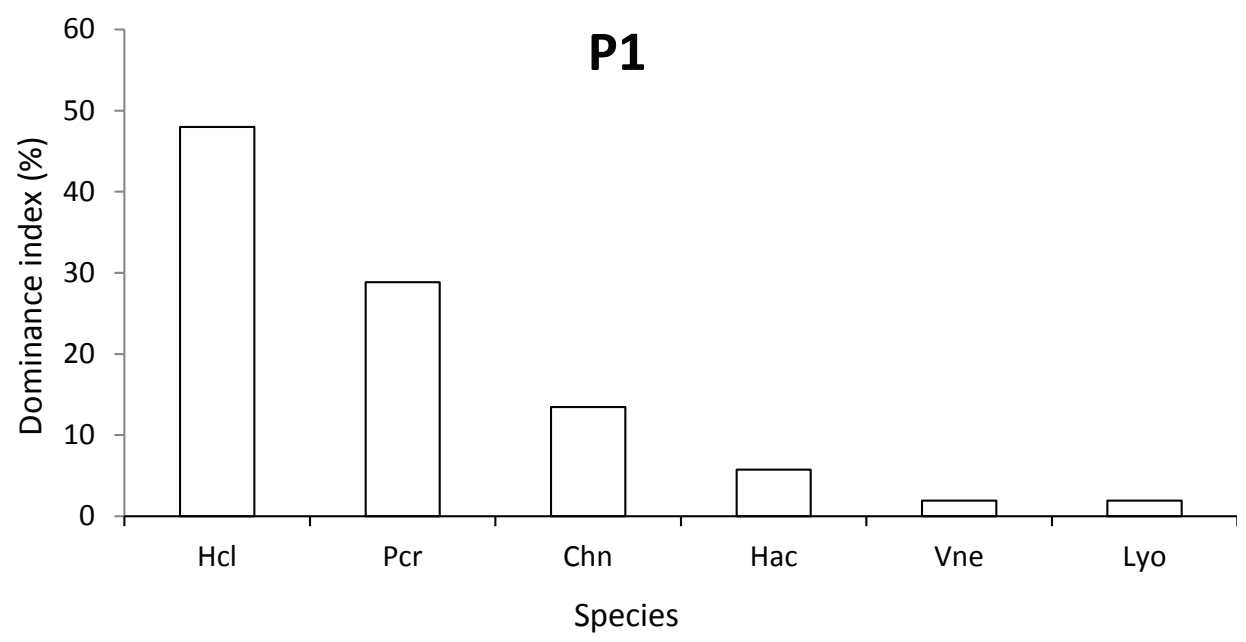

Fig. 3. Dominance structure of the mesostigmatid mite community at site $\mathrm{P} 1$ in the reclaimed mine dump in S Poland. Hcl - Hypoaspis claviger (Berlese), Pcr - Pergamasus crassipes (Linné), Chn - Cheiroseius necorniger (Oudemans), Hac - Hypoaspis aculeifer (Canestrini), Vne - Veigaia nemorensis (C. L. Koch), Lyo - Lasioseius youcefi Athias-Henriot 


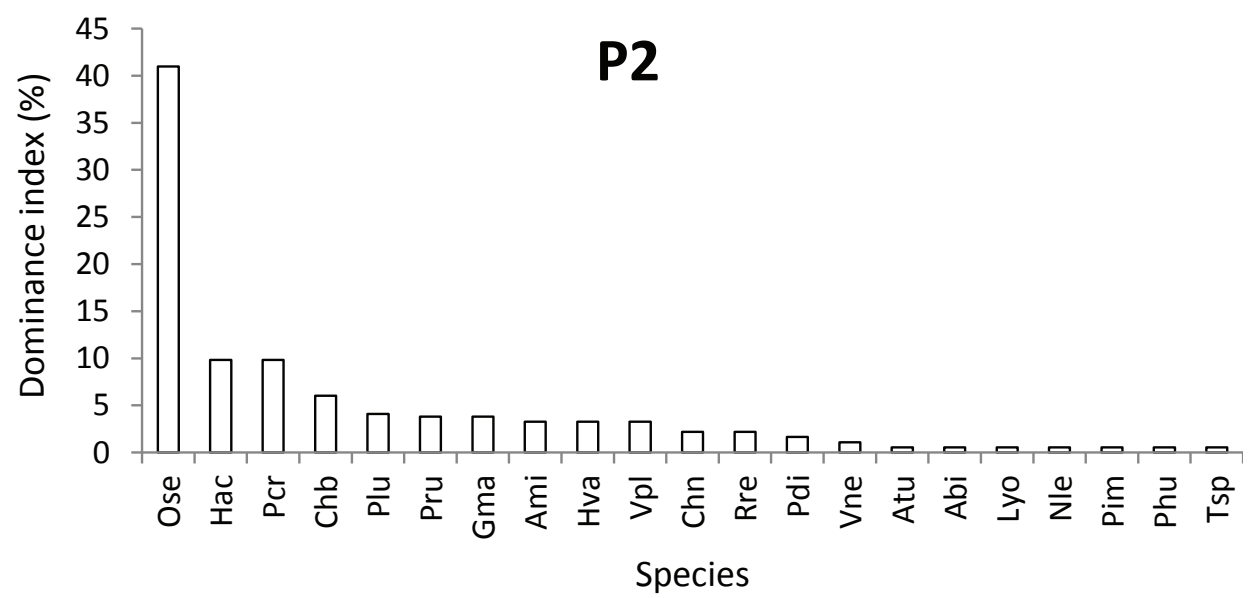

Fig. 4. Dominance structure of the mesostigmatid mite community at site $\mathrm{P} 2$ in the reclaimed mine dump in S Poland. Ose - Ololaelaps sellnicki (Bregetova, Koroleva), Hac - Hypoaspis aculeifer (Canestrini), Pcr-Pergamasus crassipes (Linné), Chb - Cheiroseius borealis (Berlese), Plu - Porrhostaspis lunulata (J. Müller), Pru - Paragamasus runcatellus (Berlese), Gma - Geholaspis mandibularis (Berlese), Ami - Amblygamasus mirabilis Willmann, Hva- Hypoaspis vacua (Michael), $\mathrm{Vpl}$ - Veigaia planicola (Berlese), Chn - Cheiroseius necorniger (Oudemans), Rre - Rhodacarus reconditus Athias-Henriot, Pdi - Paragamasus diversus (Halbert), Vne - Veigaia nemorensis (C. L. Koch), Atu - Amblyseius tubae (Karg), Abi - Asca bicornis (Can. et Fanz.), Lyo - Lasioseius youcefi Athias - Henriot, Nle - Neojordensia levis (Oudemans, Voigts), Pim - Pachylaelaps imitans Berlese, Phu - Pachyseius humeralis Berlese, Tsp - Typhlodromus sp.

had a long tail of very low-abundance species (Fig. 4). At site P3, we observed a community of lower dominance (more even distribution of abundance) and a long tail of very low abundance species (Fig. 5). The most abundant species, ranked as superdominant, was Paragamasus diversus $(D=32.6 \%)$.

The percentage of parthenogenetic individuals decreased throughout the plant succession (Fig. 6). Among the 6 Mesostigmata species found at P1, 5 were parthenogenetic. They constituted more than $67 \%$ of total abundance. The linear trend line for parthenogenesis has a very strong fit $\left(R^{2}=0.9198\right)$.

The nMDS plot showed an obvious grouping of the sites (Fig. 7) and ANOSIM indicated a strong separation of the mesostigmatid communities and significant differences between sites (global $R=0.942, p=0.001$ ). SIMPER analyses showed that the species contributing most to the dissimilarity between sites P1-P2 were $O$. sellnicki (49.39\% dissimilarity between sites). P. diversus explained about $25 \%$ of the dissimilarity between sites $\mathrm{P} 1-\mathrm{P} 3$ and $\mathrm{P} 2-\mathrm{P} 3$. The species occurred at site $\mathrm{P} 3$, with very high soil moisture (36\%) (Table 1). 
P3

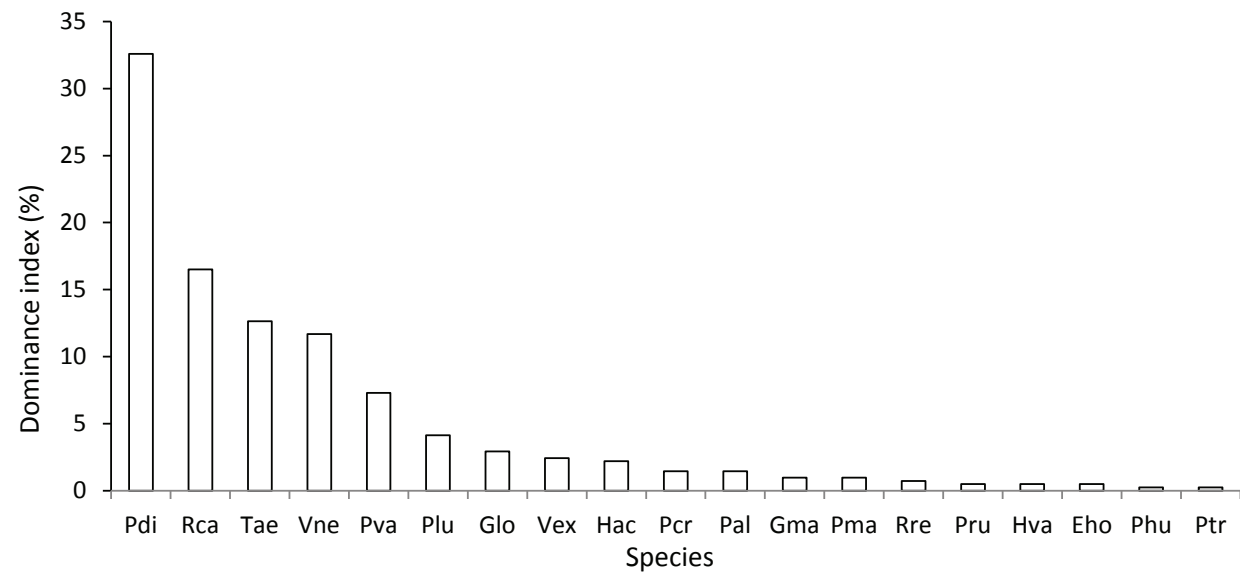

Fig. 5. Dominance structure of the mesostigmatid mite community at site P3 in the reclaimed mine dump in S Poland. Pdi - Paragamasus diversus (Halbert), Rca - Rhodacarus calcarulatus Berlese, Tae - Trachytes aegrota (C. L. Koch), Vne - Veigaia nemorensis (C. L. Koch), Pva - Paragamasus vagabundus (Karg), Plu - Porrhostaspis lunulata (J. Müller), Glo - Geholaspis longispinosus (Kramer), Vex - Veigaia exigua (Berlese), Hac - Hypoaspis aculeifer (Canestrini), Pcr - Pergamasus crassipes (Linné), Pal - Pergamasus alpestris (Berlese), Gma - Geholaspis mandibularis (Berlese), Pma - Pachylaelaps magnus Halbert, Rre - Rhodacarus reconditus Athias-Henriot, Pru Paragamasus runcatellus (Berlese), Hva - Hypoaspis vacua (Michael), Eho- Epicriopsis horridus Kramer, Phu - Pachyseius humeralis Berlese, Ptr - Prozercon traegardhi (Halbert)

$\square$ parthenogenesis $\square$ sexual

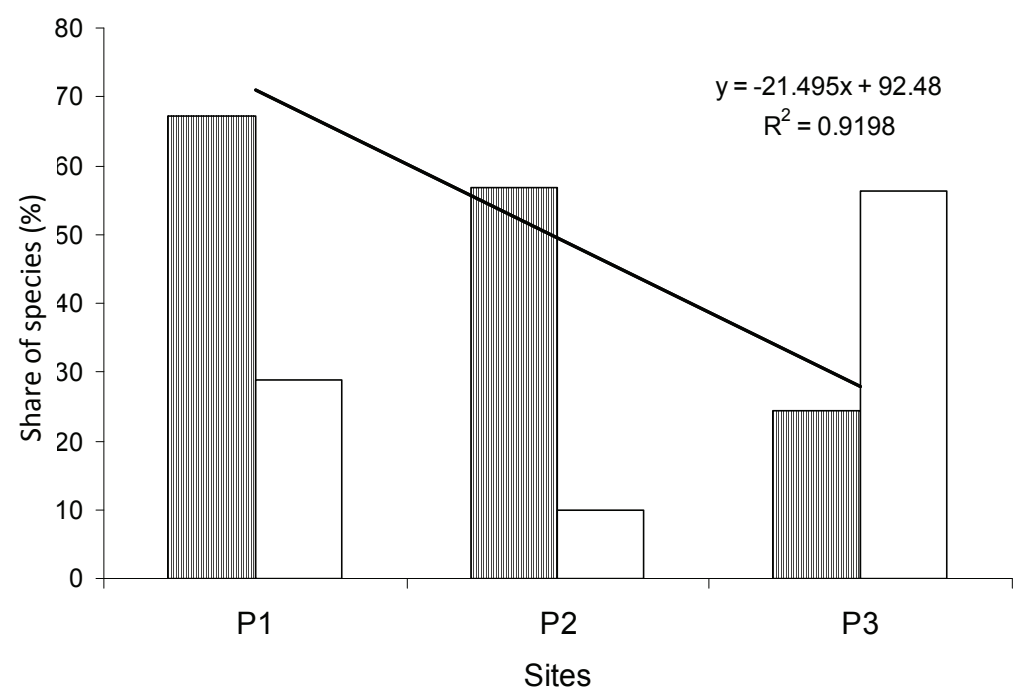

Fig. 6. Mode of mite reproduction at 3 investigated sites in the reclaimed mine dump in S Poland 


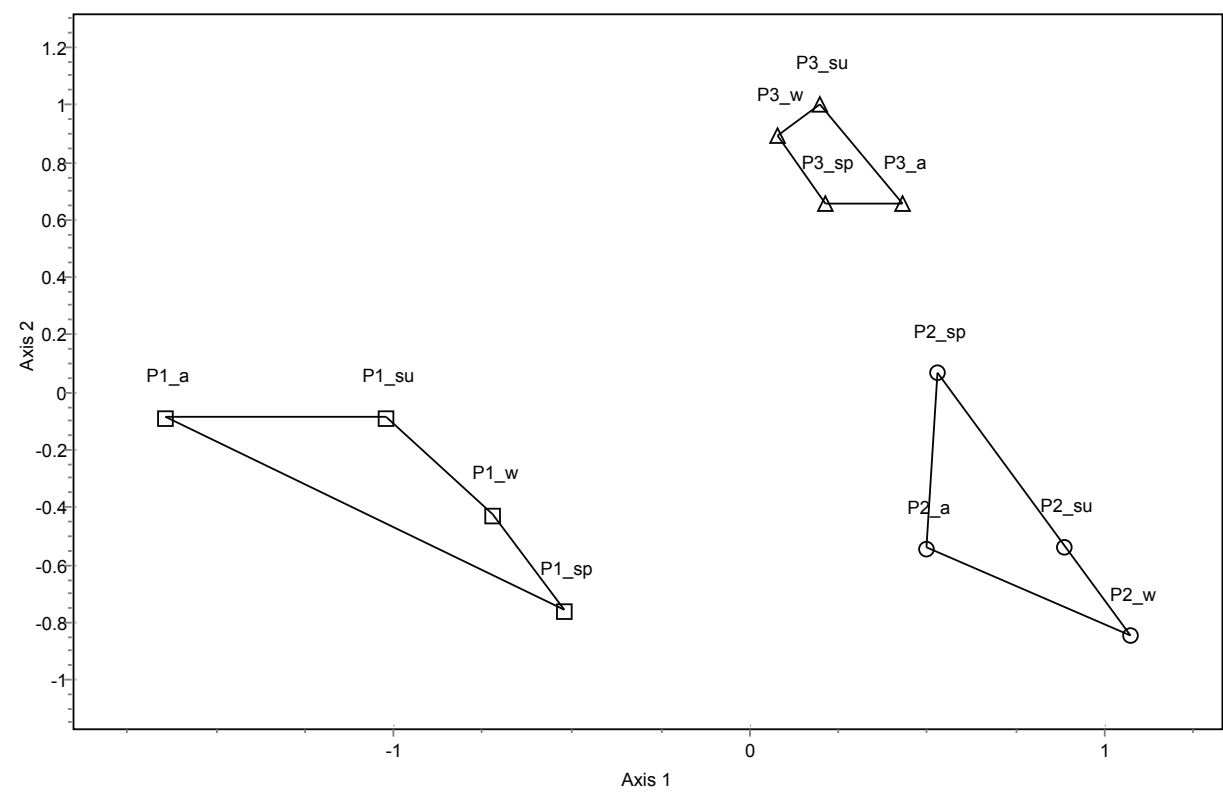

2D Stress $=0.0573902$

Fig. 7. Non-metric multidimensional scaling (nMDS) analysis of the relationship between the site samples, using $\ln (x+1)$ transformed mesostigmatid abundance at 3 investigated sites in the reclaimed mine dump in S Poland, pooled for each site from all sampling occasions ( $\mathrm{sp}$ - spring, su summer, a - autumn, $w$ - winter) (square - P1, circle - P2, triangle - P3), 2D stress: 0.0574

\section{DISCUSSION}

Chilopoda and Diplopoda need a longer time for immigration. VožENLíkOvÁ (2003), cited by HENDRYCHOVÁ (2008), documented that areas reclaimed by afforestation are poor in chilopods. The presence of saprophagous Diplopoda species shows a clear succession in parallel with mine-site development (Dunger \& VOIGTLÄNDER 2009). The eu-edaphic forms (well adapted to soil life), such as Pauropoda, Diplura, were absent. A very low abundance of Protura, typical of structured soils, was observed only at site P3.

The QBS method, using soil microarthropods for biomonitoring of soil quality, in a reclaimed mine dump, has proved to be successful in this study. A similar conclusion was reached by MADEJ et al. (2011), who analysed a chronosequence of coal mining areas, but not reclaimed.

The very high variation from the mean abundance at site P1 indicates that colonization of soils by mesostigmatid mites was very heterogeneous (RUSSELL et al. 2010). Newly reclaimed sites were rapidly colonized by these mites. In many natural and disturbed areas, Mesostigmata are early colonizers (GJelstrup 2000; ChRISTIAN 
2002; MADEJ 2004). These mites have a short generation time (KARG 1993), so they respond quickly to modifications of their environment in the process of ecological succession on reclaimed sites. They are less sensitive to environmental disturbances and can survive the extreme conditions (MinOR \& Ciancialo 2007). Many Mesostigmata are active, fast-moving predators (KoEHLER 1999). Mobile arthropod groups seem to recover faster than groups with a more limited dispersal ability (LINDBERG \& Bengtsson 2006). Different species of Mesostigmata adapt to exploit the different stages of succession. They form distinct communities. We distinguished 3 groups of species by nMDS ordination: those living in extreme habitats on bare soil with harsh conditions and poor pioneer vegetation, and on sites $\mathrm{P} 2$ and $\mathrm{P} 3$ in later stages of plant succession, respectively.

In the initial stage of succession, when the soil is most degraded, 6 mesostigmatid species survived. The first colonizers with a high dominance index at site P1 were: Hypoaspis claviger (48.1\%), Pergamasus crassipes (28.8\%), and Cheiroseius necorniger (13.5\%). The environmental conditions of this mine site were favourable enough for these species to reproduce. The species with a high ability to colonize new habitats have the best chance of survival and reproduction in extreme conditions. Phoresy is the best way to colonize new sites quickly (Athias-Binche 1994) and H. claviger can be distributed phoretically as adults (Siepel 1995). According to KOEHLER (2000), H. claviger prefers reclaimed sites. The third species mentioned above, Ch. necorniger, was found occasionally on insects (SALMANE \& BRUMELIs 2010), so it is probably also dispersed this way. Dispersal via phoresy is not known in $P$. crassipes, but according to Christian (2002), a dump overgrown with Melilotus was dominated by this species. The density of $P$. crassipes was higher in young than in old grassy arable fallows (Wissuwa et al. 2012). Passive introduction of mesostigmatid mites can be assumed when a dump was covered with turf. Together with the soil used for reclamation, probably larger or strongly sclerotized mites, such as $P$. crassipes, Ololaelaps sellnicki, Hypoaspis aculeifer, H. claviger, Paragamasus diversus, Veigaia nemorensis, and Trachytes aegrota, could be introduced into this mine dump. These include hemiedaphic carnivores, typical of forest and other later successional stages, with more intensive biological activity and humus formation (V. nemorensis, P. diversus) (PARR 1978; Schulz 1991; KARG \& FreIer 1995). According to GoRmsen et al. (2006), colonization by soil mites from transplanted turfs is not successful. Changes in flora, as well as an increase in organic matter content, result in improved conditions within the soil environment, which determines the species composition of soil animal communities (PARR 1978).

Veigaia nemorensis, $P$. diversus, and T. aegrota dominated at site P3. T. aegrota is a soil detriticole, abundant in various types of forests (MAšÁn 2003). P. diversus is known from industrial dumps afforested with Robinia, Populus, and Alnus after 33 years (Christian 1995; MADEs 2004). A high dominance of Rhodacarus calcarulatus Berlese $(16.5 \%)$ was also observed at site P3. Similarly, mites of the family Rhodacaridae dominate at later stages of succession, with woodland-like vegetation (MADej 2004). According to Ruf (1996), the Rhodacaridae are seen as a 'moderately' $K$-selected family. Presence of these species, associated with forest soils, and a fully developed dominance structure with less pronounced domination relations and 
with a larger number of accidental species (longer tail of lower-abundance species by Trojan et al. (1982) indicate an increased biotic activity at site P3. In reclaimed post-mining sites, soil formation is faster (Frouz et al. 2007). Post-mining soils after 20 years of reclamation have a well-developed organic matter horizon, similar to the organic matter of natural soils (GILEWSKA et al. 2001). Each community of Mesostigmata at the investigated sites had a distinctly different pattern of species composition and dominance structure. The rates of species turnover for successional communities increased as the communities matured. Among the edaphic mesostigmatid mites, many species are parthenogenetic. The proportion of parthenogenetic mites was the highest at site P1 (67.3\%). We found that parthenogenetic reproduction of mites tends to decrease with successional age. This is in full agreement with investigations on recovery succession of oribatid mites in disturbed areas (RYABININ \& PAN'KOV 2009). According to Siepel (1990), Koehler (1991), and Madej (2004), Mesostigmata species of the early successional stage are often phoretic or parthenogenetic.

These investigations suggest that the abundance and diversity of mesostigmatid mites increased throughout the plant succession. Pioneer plant species are effective sources of soil organic matter and increased biological activity (AROCENA et al. 2010). The vegetation promotes a more stable microclimate on the soil surface, greater habitat diversity, and influences the water regime, microflora, and soil structure (KOEHLER \& Born 1989). Plant species are major determinants of local microhabitat conditions for soil fauna (WARDLE \& LAVELlE 1997). The Mesostigmata are good indicators of development of plant cover and soil organic matter. This is in accordance with previous investigations (Koenler \& Born 1989; John et al. 2002; MAdEJ 2004). According to KoeHLer (2000), the succession of these mites is considerably influenced by reclamation.

\section{CONCLUSIONS}

The QBS index seems to be useful for monitoring the effects of reclamation of mine dumps. This index can be used for rapid assessment of soil microarthropod fauna in these anthropogenic areas. In the distinguished chronosequence, communities of mesostigmatid mites were developing gradually and differed in dominance structure and degree of organization. The share of parthenogenetic mesostigmatid species decreased during succession.

Acknowledgements: We thank Sylwia Ufnalska M.Sc. for her help in English improvement.

\section{REFERENCES}

Andrés P., Mateos E. 2006. Soil mesofaunal responses to post-mining restoration treatments. Appl. Soil Ecol. 33: 67-78.

Arocena J. M., Van Mourik J. M., Schilder M. L. M., Cano A. F. 2010. Initial Soil Development Under Pioneer Plant Species in Metal Mine Waste Deposits. Restor. Ecol. 18, S2: 244-252. 
Athias-Binche F. 1994. La phorésie chez les Acariens. Aspects adaptatifs et évolutifs [Phoresy in Acarina: Adaptive and evolutionary aspects]. Editions du Castillet, Perpignan, France (in French).

Battigelli J. P. 2011. Exploring the World Beneath your Feet - Soil Mesofauna as Potential Biological Indicators of Success in Reclaimed Soils. Proceedings - Tailings and Mine Waste, Vancouver, BC, November 6 to 9, 2011.

BLASI S. 2009. Valutazione dell'impatto antropico sulla comunità di microartropodi del suolo in alcune aree forestali dell'Italia centrale. [Evaluation of anthropogenic impact on soil microarthropod community in forest areas of central Italy]. $\mathrm{PhD}$ thesis, Università degli studi della Tuscia - Viterbo (in Italian). http://dspace.unitus.it/handle/2067/1026

BREGEtova N. G. 1977. In: Opredelitel' obitajuščich v počve kleščej Mesostigmata [Identification key of soil inhabiting mites] (GilJarov M. S. Ed.), Nauka, Leningrad (in Russian).

Снао A. 1987. Estimating population size for capture-recapture data with unequal catchability. Biometrics 43; 783-791.

Christian A. 1995. Succession of Gamasina in coal mined areas in Eastern Germany. Acta Zool. Fennica 196: 380-381.

Christian A. 2002. Colonization of primary sterile soils by epedaphic gamasina mites. In: Acarid Phylogeny and Evolution. Adaptation in mites and ticks (Bernini F., NANnelli R., NuzZaCi G., De Lillo E., Eds.), pp. 169-173, Kluwer Academic Publisher, Netherlands.

CIchY K. 2004. The Re-Development and landscaping of the "WRZOSY" disposal area at the "ANNA" coal mine in PSZÓW in order to transform the land into a recreational and sports area (report). Environmental remediation. Synthesis Report. June 2004, Ostrava seminar, Czech Republic, p. 6.

Clarke K. R. 1993. Non-parametric multivariate analyses of changes in community structure. Aust. J. Ecol. 18: 117-143.

Clarke K. R., Gorley R. N. 2001. Primer Version 5. Primer-E, Plymouth, UK.

Dickinson N. M., Hartley W., Uffindell L. A., Plumb A. N., Rawlison H., Putwain P. 2005. Robust biological descriptors of soil health for use in reclamation of brownfield land. Land Cont. \& Recl. 13: 317-326.

DUNGER W. 1989. The return of soil fauna to coal mined areas in the German Democratic Republic. In: Animals in primary succession. The role of fauna in reclaimed lands (MAJER J. D., Ed.), pp. 307-337, Cambridge University Press.

Dunger W., Voigtländer K. 2009. Soil fauna (Lumbricidae, Collembola, Diplopoda and Chilopoda) as indicators of soil eco-subsystem development in post- mining sites of eastern Germany - a review. Soil Organisms 81: 1-51.

FrouZ J., PIŽL V., TAJovsKÝ K. 2007. The effect of earthworms and other saprophagous macrofauna on soil structure in reclaimed and un-reclaimed post-mining sites in Central Europe. Eur. J. Soil Biol. 43: 184-189.

Gardi C., Montanarella L., Arrouays D., Bispo A., Lemanceau P., Jolivet C., Mulder C., RanJard L., Römbke J., Rutgers M., Menta C. 2009. Soil biodiversity monitoring in Europe: ongoing activities and challenges. Eur. J. Soil Sci. 60: 807-819.

Gardi C., Tomaselli M., Parisi V., Petraglia A., Santini C. 2002. Soil quality indicators and biodiversity in northern Italian permanent grassland. Eur. J. Soil Biol. 38: 103-110.

GawęDA A., LoRENC M. 2000. Kształtowanie i zagospodarowanie terenu zlikwidowanych osadników mułowych KWK "Rydułtowy- Anna”, Ruch "Anna” w kierunku rekreacyjno sportowym. Dział Ochrony Środowiska KWK ,Rydułtowy - Anna”.

Gilewska M., Bender J., Drzymąa S. 2001. Organic Master Formation in Post Mining Soils in Central Poland. In: Sustaining the Global Farm. Selected papers from the $10^{\text {th }}$ International Soil Conservation Organization Meeting (Stott D. E., Mohtar R. H., Steinhardth G. C., Eds.), May 24-29, 1999, Purdue University at the USDA-ARS National Soil Erosion Research Laboratory, pp. 623-626. 
Gjelstrup P. 2000. Soil mites and collembolans on Surtsey, Iceland, 32 years after the eruption. Surtsey Research 11: 43-50.

Gormsen D., Hedlund K., Wang H. F. 2006. Diversity of soil mite communities when managing plant communities on set-aside arable land. Appl. Soil Ecol. 31: 147-158.

GulviK M. E. 2007. Mites (Acari) as indicators of soil biodiversity and land use monitoring: A review. Pol. J. Ecol. 55: 415-440.

GwIżDż M. 2008. Efektywność rekultywacji biologicznej i zagospodarowania składowisk odpadów górnictwa węgla kamiennego na wybranych obiektach w rejonie Pszowa [Efficiency of biological reclamation and management of mining landfil sites, as exemplified by selected sites in the Pszów area]. MS thesis, Wrocław University of Environmental and Life Sciences, Poland (in Polish).

Hartley W., Dickinson N. M., Riby P., Shutes B. 2012. Sustainable ecological restoration of brownfield sites through engineering or managed natural attenuation? A case study from Northwest England. Ecol Eng. 40: 70-79.

Hartley W., Uffindell L., Plumb A., Rawlinson H. A, Putwain P., Dickinson N. M. 2008. Assessing biological indicators for remediated anthropogenic urban soils. Sci. Total Environ. 405: 358-369.

Hendrychoví M. 2008. Reclamation success in post-mining landscapes in the Czech Republic: A review of pedological and biological studies. J Landsc. Stud. 1: 63-78.

Hutson B. R. 1980. Colonization of industrial reclamation sites by Acari, Collembola and other invertebrates. J. Appl. Ecol. 17: 255-275.

John M. G. St., Bagatto G., Behan-Pelletier V., Lindquist E. E., Shorthousee J. D., Smith I. M. 2002. Mite (Acari) colonization of vegetated mine tailings near Sudbury, Ontario, Kanada. Plant and Soil 245: 295-305.

KARG W. 1993. Raubmilben. Acari (Acarina), Milben. Parasitiformes (Anactinochaeta) Cohors Gamasina Leach [Predatory mites. Acari (Acarina), Parasitiformes mites (Anactinochaeta) Cohors Gamasina Leach]. Die Tierwelt Deutschlands. Gustav Fisher Verlag. Jena, Stuttgart, New York (in German).

Karg W., Freier B. 1995. Parasitiforme Raubmilben als Indicatoren für den ökologischen Zustand von Ökosystemen [Parasitiforme predatory mites as Indicators of the ecological health of ecosystems]. Mitt. Biol. Bundesanstalt für Land - und Forstwirschaft. Berlin - Dahlem, 308: 1-96 (in German).

Koenler H. H. 1991. A five year study on the secondary succession of Gamasina on a ruderal site: the influence of recultivation. In: Modern acarology (Dusbabek F., Bukva V., Eds.), vol. 1, pp. 373-383, Academia, Prague and SPB Academic Publishing bv, The Hague.

Koenler H. H. 1999. Predatory mites (Gamasina, Mesostigmata). Agric. Ecosyst. Environ. 74: $395-410$.

KoeHLer H. H. 2000. Natural regeneration and succession - results from a 13 years study with reference to mesofauna and vegetation, and implications for management. Landsc. Urban Plan. 51: $123-130$.

Koenler H., Born H. 1989. The influence of vegetation structure on the development of soil mesofauna. Agric. Ecosyst. Environ. 27: 253-269.

Lindberg N., Bengtsson J. 2006. Recovery of forest soil fauna diversity and composition after repeated summer droughts. Oikos 114: 494-506.

Madej G. 2004. Rozwój zgrupowań roztoczy Mesostigmata (Arachnida, Acari) na nieużytkach poprzemysłowych [Development of communities of mesostigmatid mite (Arachnida, Acari) in areas of postindustrial wastelands]. Wydawnictwo Uniwersytetu Śląskiego, Katowice (in Polish).

Madej G., Barczyk G., Gdawiec M. 2011. Evaluation of Soil Biological Quality Index (QBS-ar): Its Sensitivity and Usefulness in the Post-Mining Chronosequence - Preliminary Research. Pol. J. Environ. Stud. 20: 1367-1372. 
MagurRan A. E. 1988. Ecological diversity and its measurement. Taylor \& Francis.

MAJER J. D. 2009. Animals in the Restoration Process-Progressing the Trends. Restor. Ecol. 17: 315-319.

MAšÁn P. 2003. Identification key to Central European species of Trachytes (Acari: Uropodina) with redescriptions, ecology and distribution of Slovak species. Eur. J. Entomol. 100: 435-448.

Menta C., Leoni A., Bardini M.,_Gardi C., Fabio G. 2008. Nematode and Microarthropod Communities: Comparative Use of Soil Quality Bioindicators in Covered Dump and Natural Soils. Environ. Bioind. 3: 35-46.

Minor M. A., Ciancialo J. M. 2007. Diversity of soil mites (Acari: Oribatida, Mesostigmata) along a gradient of land use types in New York. Appl Soil Ecol. 35: 140-153.

Múhlenberg M. 1993. Freilandökologie [Field Ecology]. Wiesbaden, UTB (in German).

Norton R. A., Kethley J. B., Johnston D. E., O’connor B. M. 1993. Phylogenetic perspectives on genetic systems and reproductive modes of mites. In: Evolution and diversity of sex ratio in insects and mites (Wrensch D. L., Ebbert M. A., Eds.), pp. 8-99, Chapman Hall, New York, London.

Oliver J. 1971. Parthenogenesis in mites and ticks (Arachnida: Acari). AM. Zool. 11: 283-299.

Oliver I., BeAttie A. J. 1993. A possible method for the rapid assessment of biodiversity. Conservation Biology 7: 562-568.

Oliver I., Beattie A. J. 1996. Invertebrate morphospecies as surrogates for species: a case study. Conserv. Biol. 10: 99-109.

Paoletti M. G. 1999. Invertebrate Biodiversity as Bioindicators of Sustainable Landscapes. Practical use of Invertebrates to assess sustainable Landuse. Elsevier.

Parisi V., Menta C., Gardi C., Jacomini C., Mozzanica E. 2005. Microarthropod communities as a tool to assess soil quality and biodiversity: a new approach in Italy. Agric. Ecosyst. Environ. 105: 323-333.

Parmenter R. R., Mac Mahon J. A. 1992. Faunal Community Development on Disturbed Lands: An Indicator of Reclamation Success. Evaluating Reclamation Success: The Ecological Consideration - Proceedings of A symposium: 73-89.

PARR T. W. 1978. An analysis of soil microarthropod succession. Sci. Proc. R. Dublin Soc., Ser. A, 6: $185-196$.

RuF A. 1996. Life - history patterns in soil-inhabiting Mesostigmatid mites (Dermanyssina, Parasitina). In: Acarology (Mitchell R., Horn D. J., Needham G. L., Welbourn W. C., Eds.). vol. 9, pp. 621-628, Ohio Biological Survey. Columbus, Ohio.

Russell D. J., Hohberg K., Elmer M. 2010. Primary colonisation of newly formed soils by actinedid mites. Soil Org. 82: 237-251.

Ryabinin N. A., Pan'kov A. N. 2009. Successions of Oribatid Mites (Acariformes: Oribatida) on Disturbed Areas. Izvestiya Akademii Nauk, Seriya Biologicheskaya 5: 604-609.

Salmane I., Brumelis G. 2010. Species list and habitat preference of Mesostigmata mites (Acari, Parasitiformes) in Latvia. Acarologia 50: 373-394.

Santorufo L., Van Gestel C. A. M., Rocco A., Maisto G. 2012. Soil invertebrates as bioindicators of urban soil quality. Environ. Pollut. 161: 57-63.

Schulz E. 1991. Die Milbenfauna (Acari: Gamasina, Uropodina, Oribatei) in verschiedenen Lebensräumen auf Kalkgestein: Populationökologie, Sukzession und Bieziehungen zum Lebensraum [The mite fauna (Acari: Gamasina, Uropodina, Oribatei) in different habitats on limestone: population ecology, succession and adaptation to habitat]. Berichte des Forschungszentrums Waldökosysteme, Reihe A, 79: 1-245 (in German).

Seaby R. M. H., Henderson P. A. 2006. Species Diversity \& Richness. Pisces Conservation Ltd.

Seaby R. M. H., Henderson P. A. 2007. Community Analysis Package 4. Pisces Conservation Ltd.

SiePel H. 1990. Decomposition of leaves of Avenella flexuosa and microarthropod succession in grazed and ungrazed grassland. I. Succession of microarthropods. Pedobiologia 34: 19-30. 
Siepel H. 1995. Applications of microarthropod life-history tactics in nature management and ecotoxicology. Biol. Fertil. Soils 19: 75-83.

Topp W., Simon M., Kautz G., Dworschak U., Nicolini F., Prückner S. 2001. Soil fauna of a reclaimed lignite open-cast mine of the Rhineland: improvement of soil quality by surface pattern. Ecol. Eng. 17: 307-322.

Trojan P., Górska D., Wegner E. 1982. Processes of synanthropization of competitive animal association. Memorab. Zool. 37: 125-135.

Turbé A. De Toni A., Benito P., Lavelle P., Lavelle P., Ruiz N., Van Der Putten W. H., Labouze E., Mudgal S. 2010. Soil biodiversity: functions, threats and tools for policy makers. Bio Intelligence Service, IRD, and NIOO, Report for European Commission (DG Environment), 2010.

Turnhout E., Hisschemöller M., Eijsackers H. 2007. Ecological indicators: between the two fires of science and policy. Ecol. Indic. 7: 215-228.

Walter D. E., Kaplan D. T. 1990. A guild of thelytokous mites (Acari: Mesostigmata) associated with citrus roots in Florida. Environ. Ent. 19: 1338-1343.

Walter D. E., Lindquist E. E. 1995. The distributions of parthenogenetic ascid mites (Acari: Parasitiformes) do not support the biotic uncertainty hypothesis. Exp. Appl. Acarol. 19: 423-442.

Walter D. E., Oliver J. H. JR. 1989. Geolaelaps oreithyiae, n. sp. (Acari: Laelapidae), a thelytokous predator of arthropods and nematodes, and a discussion of clonal reproduction in the Mesostigmata. Acarologia 30: 293-303.

WAnNer M., Dunger W. 2002. Primary immigration and succession of soil organisms on reclaimed opencast coal mining areas in eastern Germany. Eur. J. Soil Biol. 38: 137-143.

Wardle D. A., LAVelle P. 1997. Linkages between soil biota, plant litter quality and decomposition. In: Driven by Nature: Plant Litter Quality and Decomposition (CADISCH G., GILLER K. E., Eds.), pp. 107-124, CAB International, Wallingford.

Wissuwa J., Salamon J. A., Frank T. 2012. Effects of habitat age and plant species on predatory mites (Acari, Mesostigmata) in grassy arable fallows in Eastern Austria. Soil Biol. Biochem. 50: 96-107.

WitT B. 1997. Using Soil Fauna to Improve Soil Health. Restor. Recl. Rev. 2: 1-5.

Yan S., Singh A. N., Fu S., Liao C., Wang S., Li Y., Cui Y., Huf L. 2011. A soil fauna index for assessing soil quality. Soil Biol. Biochem. 47: 158-165. 